\title{
Evolutionary convergence in conodonts revealed by Synchrotron-based Tomographic Microscopy
}

\author{
Michele Mazza and Carlos Martínez-Pérez
}

\begin{abstract}
The conodont fossil record is well known for its morphological diversity, but the iterative evolution that characterizes conodonts often avoids providing reliable phylogenetic frameworks among species, making unclear if the diagnostic characters of the taxa are indicative of common ancestry or evolutionary convergences. To distinguish homologies from analogies in conodonts, the most reliable method is by studying the ontogenetic development of the single taxa. Until now, the reconstruction of the ontogenetic stages was based on the study of separate individuals at different age from single populations. Nevertheless, the only unequivocal way to describe the ontogenesis of a conodont is to describe it from a single specimen. We achieve this objective by using Synchrotron Radiation X-ray Tomographic Microscopy applied to $\mathrm{P}_{1}$ elements of species belonging to the Upper Triassic genera Carnepigondolella and Epigondolella. Our analysis provided internal tomographic information for the reconstruction of the conodont ontogenesis. We focused our study on the posterior platform, where an accessorial node develops behind the cusp. This node resulted in an autapomorphy of the genus Epigondolella from previous cladistic analyses and, thus, a diagnostic character for the elaboration of phylogenetic models. The microtomographies showed that this character is instead an evolutionary convergence. These results suggest the revision of the Late Triassic conodont phylogenetic relationships, showing that ontogenesis can be used as a criterion for discriminating homology from homoplasy in conodonts, and demonstrating that Synchrotron Radiation X-ray Tomographic Microscopy is a powerful and reliable tool to investigate conodont ontogenesis, evolutionary processes and phylogenetic relationships.
\end{abstract}

Michele Mazza. Dipartimento di Scienze della Terra "A. Desio", Università degli Studi di Milano, Via Mangiagalli 34, 20133, Milano (Italy); michele.mazza@unimi.it; mazza_michele@yahoo.it Carlos Martínez-Pérez. Departamento de Geología, Universidad de Valencia, Avda. Dr. Moliner, 50, 46100 Burjassot, Valencia (Spain); carlos.martinez-perez@uv.es; School of Earth Sciences, University of Bristol, Wills Memorial Building, Queen's Road, Bristol BS8 1RJ, UK; carlos.martinez-perez@uv.es

Keywords: conodonts; X-ray tomographies; ultrastructure; ontogenesis; Triassic

Submission: 11 May 2016 Acceptance: 23 November 2016

Mazza, Michele and Martínez-Pérez, Carlos. 2016. Evolutionary convergence in conodonts revealed by Synchrotron-based Tomographic Microscopy. Palaeontologia Electronica 19.3.52A: 1-11

palaeo-electronica.org/content/2016/1710-conodont-x-ray-tomographies 


\section{INTRODUCTION}

The conodont fossil record constitutes a rich archive of evolutionary history, in terms of its temporal extent, from Cambrian to Triassic, and its completeness (Foote and Sepkoski, 1999). Functional analyses have advanced to an extent where conodont taxonomy, based on dental morphology, can be interpreted in terms of feeding ecology (Jones et al., 2012a, 2012b; Purnell and Jones, 2012; Martínez-Pérez et al., 2014a, 2014b, 2016; Murdok et al., 2014). This opens the possibility of interpreting the conodont fossil record as a detailed and comparatively complete record of the evolution of feeding ecology through much of the Phanerozoic, including across some of the most dramatic ecological and environmental crises that have impacted animal life, such as the end-Ordovician, Frasnian-Fammenian, Hangenberg, and PermianTriassic mass extinction events. Realizing this vision requires a coherent phylogeny for conodonts on which to trace the evolution of feeding ecology. To this end, attempts have been made to establish a phylogeny for conodonts using cladistics (Donoghue, 2001; Zhang and Barnes, 2004; Wickström and Donoghue, 2005; Donoghue et al., 2008; Mazza et al., 2012b), but this aim is challenged by widespread morphological convergence in disparate conodont lineages (Sweet, 1988; Dzik, 2005). Here, we explore the utility of ontogenetic evidence, in the form of growth arrest lines that record the morphogenesis of conodont elements, showing that they can be used to discriminate between homologous and convergent adult morphologies. Until now, the reconstruction of the different ontogenetic stages was based on the study of isolated specimens from single populations, but several problems normally arise in order to distinguish between juvenile specimens of related species that did not develop their characteristic morphologies until more developed stages. Hence, the only unequivocal way to describe the ontogenesis is by describing it from a single element. A first step forward in this direction has recently been made by Mazza and Martínez-Pérez (2015), who used Synchrotron data to test and verify the reconstructions of 10 ontogenetic series of Carnian-Norian (Late Triassic) platform conodont species. In this study a higher level of detail is reached in the use of the XRay Tomography Microscopy, reconstructing the ontogenetic mechanisms of a single morphological character in order to unravel homology from homoplasy in conodonts.

\section{MATERIAL AND CASE STUDY}

The present work is focused on the $P_{1}$ elements of Late Triassic gondolellid conodonts from the Neotethyan Province. Our study is based on seven phylogenetically related species belonging to the genera Carnepigondolella (C. pseudodiebeli) and Epigondolella (E. miettoi, E. quadrata, E. vialovi, E. rigoi, E. triangularis, and E. uniformis), ranging from the Upper Carnian (Tuvalian) to the Lower Norian (Lacian) (Table 1). The studied conodonts have Colour Alteration Index (CAI) values of 1.5 or 7 (Epstein et al., 1977). All the specimens are stored at the Dipartimento di Scienze della Terra "A. Desio" of the Università degli Studi di Milano (see Table 1 for the repository numbers).

The material comes entirely from the Upper Triassic (Upper Carnian-Rhaetian) section of Pizzo Mondello (western Sicily, Italy), GSSP candidate for the Norian stage (Muttoni et al., 2001, 2004; Nicora et al., 2007; Balini et al., 2011, 2012, 2015; Mazza et al., 2012a, 2012b; Mazza and Krystyn, 2015).

The Carnepigondolella-Epigondolella lineage constitutes a worthy case of study, because it is the only conodont phylogenetic lineage encompassing the Carnian/Norian boundary and evolving into the last Middle Norian and Rhaetian taxa (i.e., genera Mockina, Parvigondolella, and Misikella), which are the last conodont representatives (MartínezPérez et al., 2014c). In addition, previous innovative studies on this lineage (Mazza et al., 2012b) provide a solid evolutionary framework to be tested. The phylogenetic relationships of the species composing this lineage were first investigated using numerical cladistic analyses (Mazza et al., 2012b; Figure 1). In these analyses, some morphological characters of the posterior platform resulted in autapomorphies that defined the most derived taxa of the Epigondolella clade. These were the development of denticles on the posterior platform margin together with the enlargement of the posterior platform, and the occurrence of a large carinal node behind the cusp. In addition, the platform development (ontogenesis) of some carnepigondolellids and epigondolellids, considered also in the present study, were recently described by Mazza and Martínez-Pérez (2015), using both growth series and X-ray tomographies. This study also provided the tools to give a specific taxonomic identity to the most juvenile conodont forms. Nevertheless, those results produced some discrepancies between the new conodont ranges that emerged with the classification of the juvenile specimens and the previous cladistic phylogenetic 
TABLE 1. List of the conodonts scanned at the X-ray Synchrotron Microscopy for analyses of the internal structure. Species for which more than one specimen was scanned are provided with a capital letter that, associated with the species name, identify the specimen in the text and in figures. All the specimens are from the Pizzo Mondello section (western Sicily, Italy).

\begin{tabular}{|c|c|c|c|c|}
\hline Species & Epigondolella vialovi & Epigondolella quadrata & Epigondolella quadrata & Epigondolella quadrata \\
\hline Author and year & (Burij, 1989) & Orchard, 1991 & Orchard, 1991 & Orchard, 1991 \\
\hline Specimen & & A & B & $\mathrm{C}$ \\
\hline $\begin{array}{l}\text { Range of the } \\
\text { species }\end{array}$ & $\begin{array}{l}\text { Upper Carnian - } \\
\text { Lower Norian }\end{array}$ & $\begin{array}{l}\text { Upper Carnian - } \\
\text { Middle Norian }\end{array}$ & $\begin{array}{l}\text { Upper Carnian - } \\
\text { Middle Norian }\end{array}$ & $\begin{array}{l}\text { Upper Carnian - } \\
\text { Middle Norian }\end{array}$ \\
\hline Sample & NA30 & NA60 & NA60 & NA66 \\
\hline $\begin{array}{l}\text { Age of the } \\
\text { sample }\end{array}$ & $\begin{array}{l}\text { Uppermost Tuvalian } \\
\text { (Upper Carnian) }\end{array}$ & $\begin{array}{l}\text { Upper Lacian } \\
\text { (Lower Norian) }\end{array}$ & $\begin{array}{l}\text { Upper Lacian } \\
\text { (Lower Norian) }\end{array}$ & $\begin{array}{l}\text { Upper Lacian } \\
\text { (Lower Norian) }\end{array}$ \\
\hline $\begin{array}{l}\text { Repository } \\
\text { number }\end{array}$ & $\begin{array}{l}\text { Micro-Unimi } \\
\text { no. } 2010\end{array}$ & $\begin{array}{l}\text { Micro-Unimi } \\
\text { no. } 2011\end{array}$ & $\begin{array}{l}\text { Micro-Unimi } \\
\text { no. } 2012\end{array}$ & $\begin{array}{l}\text { Micro-Unimi } \\
\text { no. } 2017\end{array}$ \\
\hline CAI & 1.5 & 7 & 7 & 1.5 \\
\hline Species & Epigondolella rigoi & Epigondolella rigoi & Epigondolella uniformis & $\begin{array}{c}\text { Epigondolella } \\
\text { triangularis }\end{array}$ \\
\hline Author and year & Noyan and Kozur, 2007 & Noyan and Kozur, 2007 & (Orchard, 1991) & (Budurov, 1972) \\
\hline Specimen & A & B & & \\
\hline $\begin{array}{l}\text { Range of the } \\
\text { species }\end{array}$ & Lower - Middle Norian & Lower - Middle Norian & Lower - Middle Norian & Lower Norian \\
\hline Sample & NA61 & NA60 & NA42 & NA44a \\
\hline $\begin{array}{l}\text { Age of the } \\
\text { sample }\end{array}$ & $\begin{array}{l}\text { Upper Lacian } \\
\text { (Lower Norian) }\end{array}$ & $\begin{array}{l}\text { Upper Lacian } \\
\text { (Lower Norian) }\end{array}$ & $\begin{array}{l}\text { Lower Lacian } \\
\text { (Lower Norian) }\end{array}$ & $\begin{array}{l}\text { Lower Lacian } \\
\text { (Lower Norian) }\end{array}$ \\
\hline $\begin{array}{l}\text { Repository } \\
\text { number }\end{array}$ & $\begin{array}{l}\text { Micro-Unimi } \\
\text { no. } 2018\end{array}$ & $\begin{array}{l}\text { Micro-Unimi } \\
\text { no. } 2014\end{array}$ & $\begin{array}{l}\text { Micro-Unimi } \\
\text { no. } 2013\end{array}$ & $\begin{array}{l}\text { Micro-Unimi } \\
\text { no. } 2015\end{array}$ \\
\hline CAI & 7 & 1.5 & 1.5 & 1.5 \\
\hline
\end{tabular}

model (Figure 1). In particular, the phylogenetic position of E. vialovi, E. quadrata, E. rigoi, E. uniformis, and $E$. triangularis became uncertain, because their stratigraphic ranges are now prolonged downwards in the Upper Carnian and not limited to the Lower Norian as before, questioning their previous phylogenetic relationships (Mazza and Martínez-Pérez, 2015, figure 1). It is evident that convergences between species were misinterpreted as homologies with phylogenetic value. In particular, the accessorial node behind the cusp that resulted in an autapomorphy in Mazza et al. (2012b) and defined the Epigondolella clade, seemed to be developed at different ontogenetic stages in the epigondolellids (see Mazza and Martínez-Pérez, 2015). Thus, in an attempt to discriminate between homology and homoplasy, we undertook a detailed analysis of the morphogenesis of what seems to be a key character to shed light on the evolutionary scenario of the Late Carnian/Norian conodonts.

\section{METHODS}

We characterise the inner growth patterns of the different species using the synchrotron radiation X-Ray Tomography Microscope at the X02DA TOMCAT beamline of the Swiss Light Source, Paul Scherrer Institute (Villigen, Switzerland), a technique that allows non-invasive, high resolution, quantitative and volumetric $x$-ray tomographies on diverse samples. The specimens were scanned using a 20x objective, with exposure time between 83 to $270 \mathrm{~ms}$ at $10-14 \mathrm{keV}$, acquiring 1501 projections equiangularly over 180 degrees. Isotropic voxel dimensions are $0.325 \mu \mathrm{m}$. Projections were post-processed and rearranged into flat- and darkfield-corrected sinograms, and reconstruction was performed on a 60-core Linux PC farm using a Fourier transform routine and a regridding procedure (Marone and Stampanoni, 2012). The reconstructed files were analyzed and manipulated using AVIZO v.8 (VSG), allowing us to extract accurate $3 D$ virtual models, and virtual thin sections that were created using the voltex module, which simulates the casting of light rays from preset sources 




FIGURE 1. Cladogram representing the Epigondolella clade of Mazza et al. (2012b), illustrating the phylogenetic relationships between the Upper Carnian-Lower Norian (Upper Triassic) carnepigondolellids and epigondolellids and their main evolutionary trends. Only the species analysed in this work are figured. The specimens of $E$. vialovi, $E$. quadrata, E. uniformis, and E. triangularis are from Mazza and Martínez-Pérez (2015). Vertical bars beside the specimens indicate the platform $(\mathrm{P})$ /blade $(B)$ length ratio; white circles mark the cusp. All the specimens are at the same scale.

through a volume of data. This technique permitted us to generate multiple sections of the analyzed specimens in all the desired directions, providing a complete control on the area of the conodont that we want to investigate (Figure 2). Horizontal sections of the entire element of the epigondolellids considered in this study were already employed in Mazza and Martínez-Pérez (2015) to verify the reliability of the reconstructed conodont ontogenetic series. The excellent correspondence between the juvenile stages outlined by the growth lines in the X-ray sections and juvenile specimens photographed at the SEM used for the growth series, proved the validity of the technique. In this work, we analyze for the first time cross and longitudinal sections perpendicular to the longitudinal axis of the platform and parallel to the platform surface, respectively (Figure 2).

Microtomographic sections were compared with scanning electron microscopy (SEM) photos of artificially fractured specimens from the same samples in order to demonstrate the degree of detail of the synchrotron analyses (Figure 3). The artificial fractures have been produced across the longitudinal axes of the platforms with a common needle, etched with $0.5 \%$ orthophosphoric acid for 2-4 minutes and coated with gold previous to the SEM analysis.

\section{RESULTS}

Tomographic images of the conodonts ultrastructure were obtained from all the scanned elements, but with variable levels of detail from specimen to specimen. The best results were obtained on conodonts with CAI value 7 (see Table 1), probably induced by hydrothermal alteration (Rejebian, 1987). These conodonts show the best contrast between the growth lines and the highest number of visible details in the ultrastructure (Fig- 


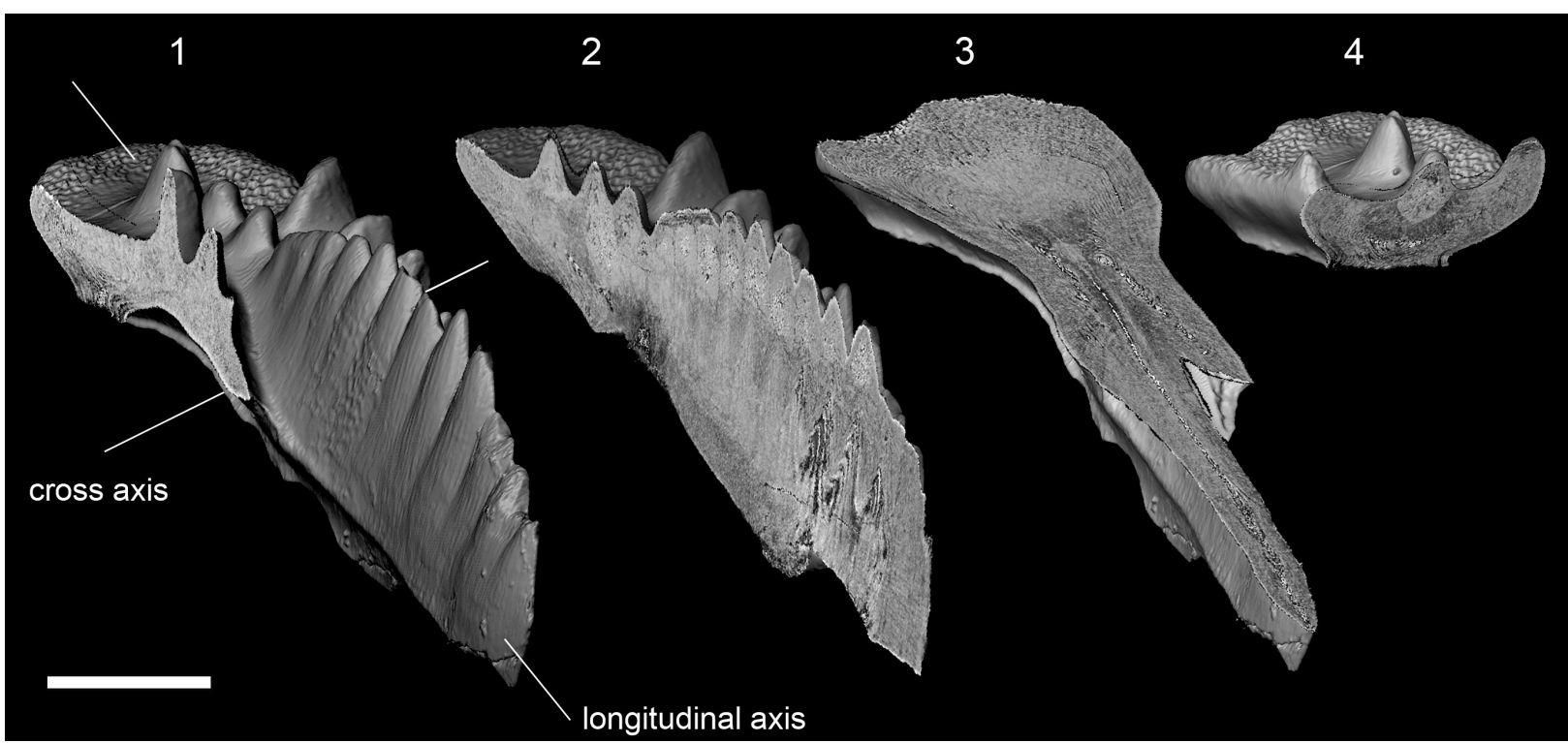

FIGURE 2. X-ray Synchrotron microtomography of Epigondolella quadrata specimen A. Three possible sections that can be obtained with the X-ray synchrotron microscopy are shown. 1, 3D model of the specimen: 2, Longitudinal section; 3, Horizontal section; 4, Cross section. Scale bar equals $200 \mu \mathrm{m}$.

ure 3.1). No differences of preservation or other sign of alteration were observed on specimens with CAl 1.5 that could affect the X-ray analyses.

Conodont crown tissue is basically constituted by two main components, the hyaline lamellar tissue and the white matter (Donoghue, 1998 and references herein), both clearly recognizable in the tomographic reconstructions. Lamellar tissue is composed by prismatic crystallites organized in growth lines (i.e., lamellae). In the microtomographic sections, these growth lines appear as bright and parallel lines, separated by darker gaps (interlamellar space) of variable thickness (Figure $3)$. On the other hand, the white matter, a hard tissue that shows a more compact structure than the previous one, is characterized by a dense porous structure that gives to this tissue a typical cancellated appearance (Donoghue, 1998). In the microtomographic sections the white matter is easily distinguishable, being brighter than the lamellar tissue in all the analysed specimens and CAI values, and showing a coarse granulated appearance given by the porosity of the tissue (Figure 3). As shown in the microtomographies, its distribution is limited only to the blade denticles and carinal nodes.

\section{Ontogenesis of the Posterior Node}

We focused our X-ray microtomographic analyses on the posterior platform, particularly diagnostic for the terminal taxa of the Epigondolella clade (Mazza et al., 2012b; Mazza and Martínez-Pérez,
2015). In Carnepigondolella pseudodiebeli and E. miettoi the cusp is the last node of the carina but, in the descendant epigondolellids, the cusp shifts forward and a larger carinal node starts developing behind the cusp (Figure 1). This character was interpreted by previous cladistic analyses as an autapomorphy shared by all the most derived epigondolellids (Mazza et al., 2012b). In all the scanned specimens the cusp is always easily distinguishable in longitudinal section due to the massive occurrence of white matter that permeates the entire node from its tip to the basal cavity (Figures $4,5)$. Local tomographic sections that longitudinally cuts the cusp and the posterior node of $E$. quadrata show, in all the three analyzed specimens of this species, growth lines developing from the cusp and building a short posterior platform margin (Figure $4.1,3-4)$. In the younger growth stages, no carinal nodes occur behind the cusp of $E$. quadrata, as seen in a juvenile specimen of the same species, sampled from an $E$. quadrata monospecific population (Figure 4.2) and illustrated also in the growth series of Mazza and Martínez-Pérez (2015, plate 3 , p. 171). The posterior node starts developing only later in age: a series of hypocalcifications, increasing in size with age, may be observed growing from the juvenile posterior platform margin and originating what was previously regarded as a carinal node (Figure 4.4).

In Epigondolella rigoi, instead, the supposed direct descendant species of E. quadrata (Noyan and Kozur, 2007; Mazza et al., 2012b), the onto- 


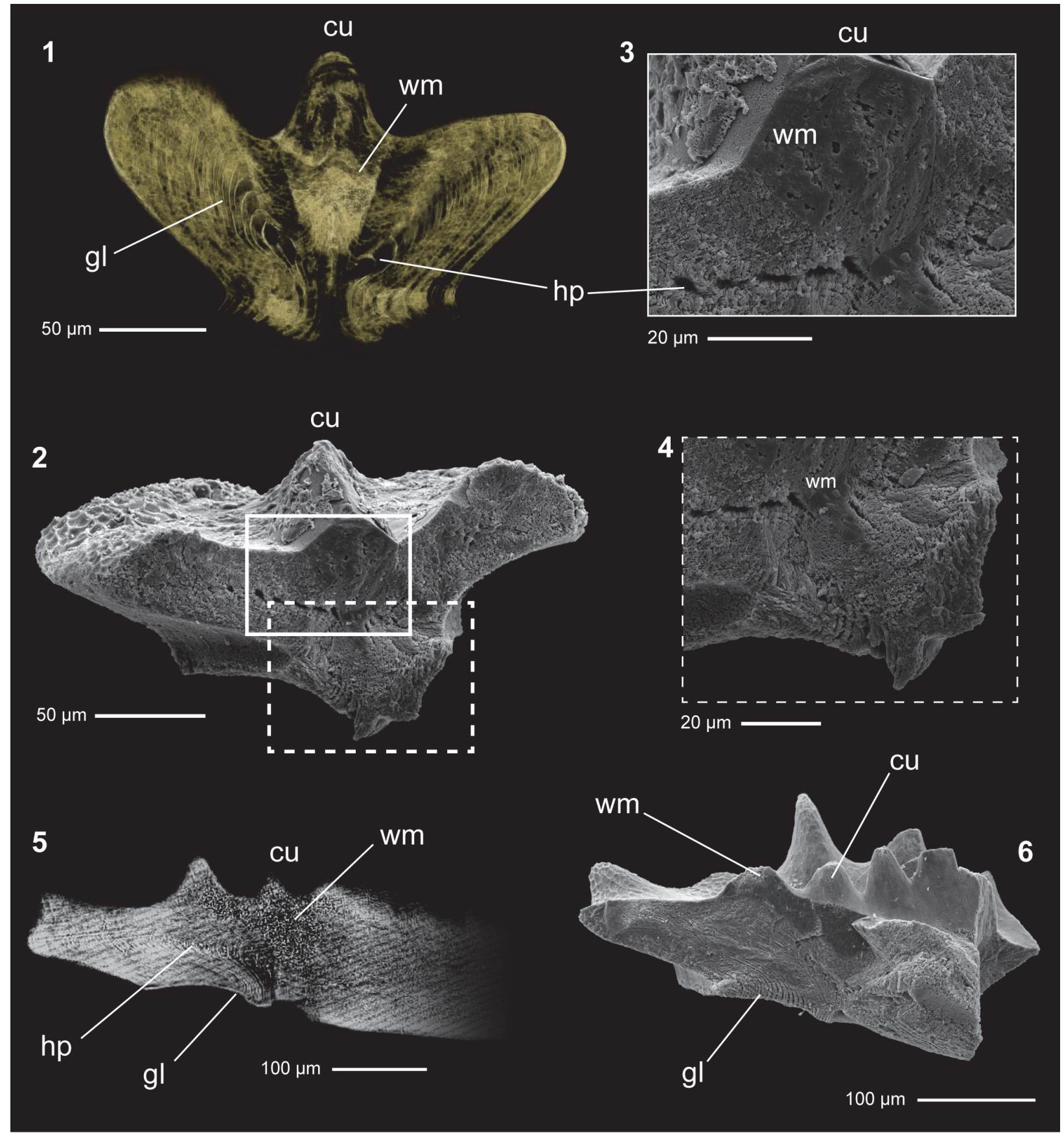

FIGURE 3. X-ray synchrotron microtomographic sections compared to SEM photos of artificially fractured conodont specimens. 1, Tomographic section of Epigondolella quadrata specimen A; 2-4, SEM photos of an artificially fractured specimen of Carnepigondolella carpathica (sample NA16). Both the specimens are sectioned in correspondence to the cusp; 5-6, Comparison between a tomographic section (5) and an artificially fractured (6) specimen of E. uniformis from the same sample (NA42). Legend: cu, cusp; wm, white matter; hp, hypocalcification; gl, growth lines.

genesis of the posterior node is completely different (Figure 4.5-7). A focused longitudinal section of the cusp region of the two analyzed E. rigoi specimens reveals that the youngest growth stages of the posterior node are not yet interested by white matter, and it allows us to observe the early ontogenetic stages of this character (Figure 4.5). The microtomography clearly shows that, unlike in $E$. quadrata, in E. rigoi the lamellae constituting the posterior node grow directly from the cusp since 


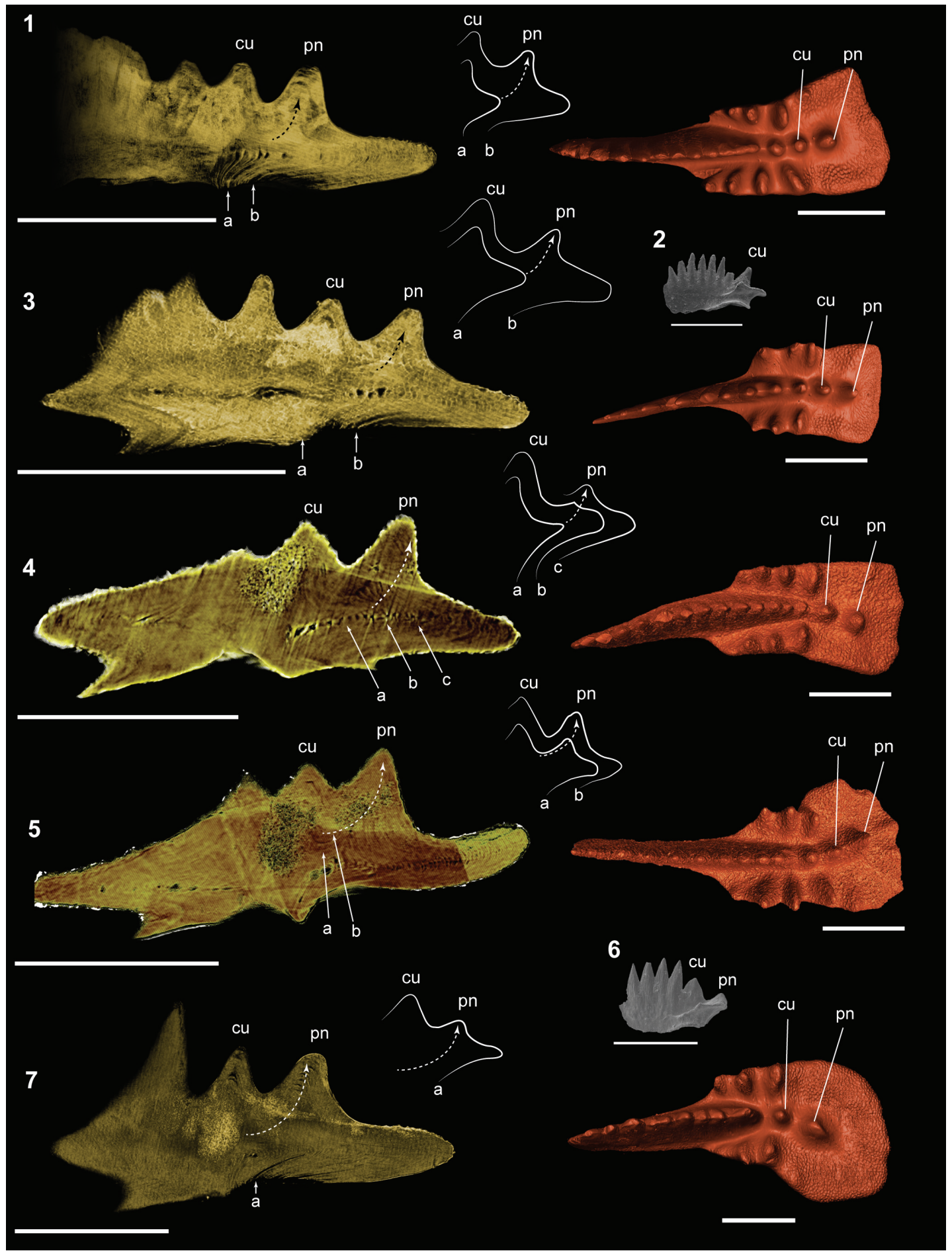

FIGURE 4. Microtomographic longitudinal sections focused on the posterior platform of Epigondolella quadrata and E. rigoi, aimed to show the ontogenesis of the posterior node growing behind the cusp. For each section a 3D model of the correspondent conodont is provided. Beside the sections, the outlines of selected growth lines are reported, in order to evidence some visible growth stages and show the different ontogenetic processes of $E$. quadrata and $E$. rigoi. Arrows and letters $(a, b, c)$ mark the growth lines considered to draw the stages. 1, E. quadrata A; 2, juvenile specimen of $E$. quadrata from sample NA60 (from Mazza and Martínez-Pérez, 2015; repository number Micro-Unimi no. 2001); 3, E. quadrata B; 4, E. quadrata C; 5 , E. rigoi A; 6 , juvenile specimen of E. rigoi from sample NA68 (from Mazza and Martínez-Pérez, 2015; repository number Micro-Unimi no. 2003), showing that the posterior node is already occurring; 7, E. rigoi B. Scale bars equal $200 \mu \mathrm{m}$. Legend: cu, cusp; pn, posterior node. 


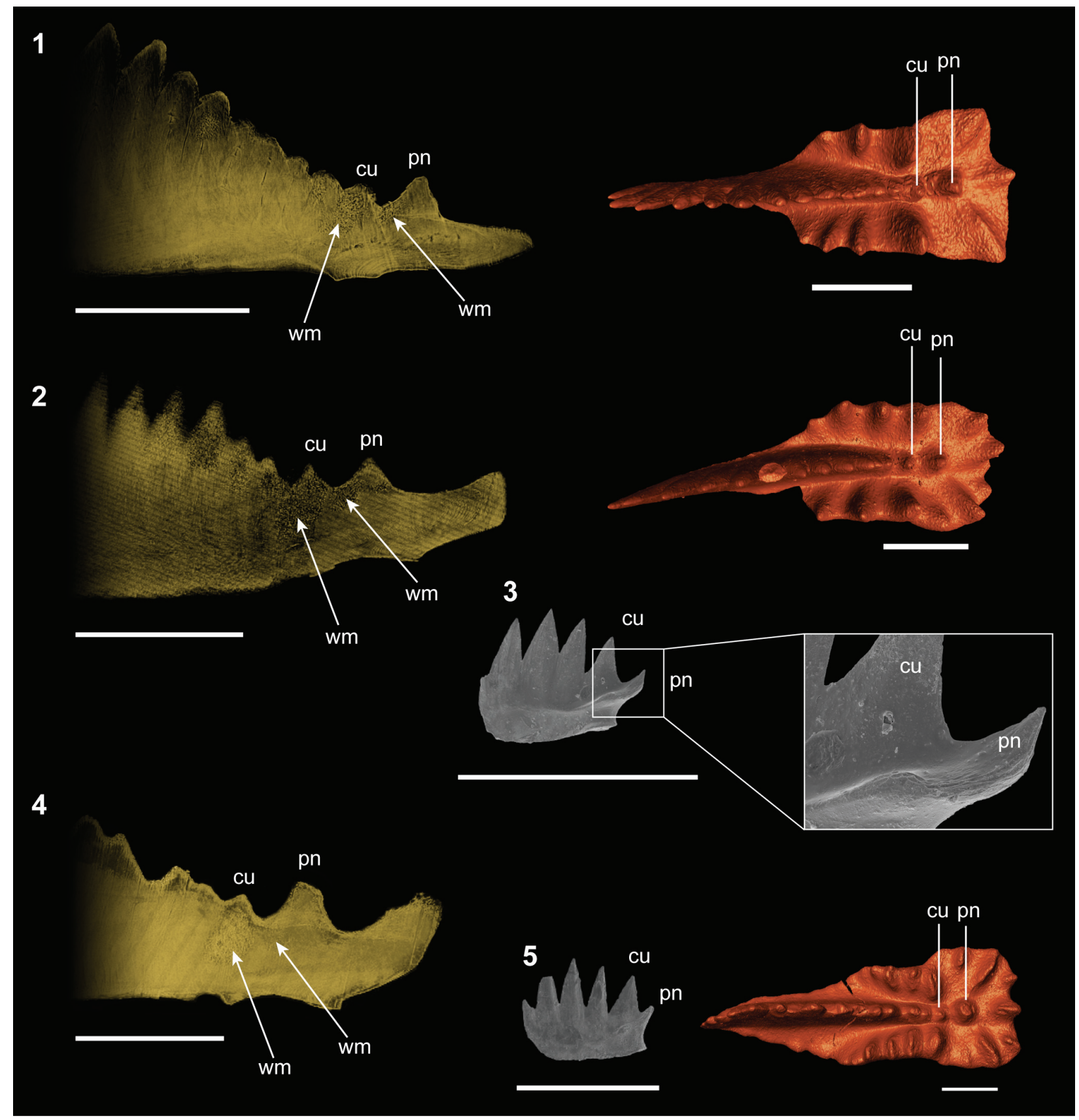

FIGURE 5. Microtomographic longitudinal sections focused on the posterior platform of Epigondolella vialovi, E. uniformis, and E. triangularis aimed to show the ontogenesis of the posterior node growing behind the cusp. For each section a 3D model of the correspondent conodont is provided. 1 , E. vialovi; 2, E. uniformis; 3, juvenile specimen of $E$. uniformis from sample NA43 (from Mazza and Martínez-Pérez, 2015; repository number Micro-Unimi no. 2005); 4, E. triangularis; 5, juvenile specimen of E. triangularis from sample NA43 (from Mazza and Martínez-Pérez, 2015; repository number Micro-Unimi no. 2004). Scale bars equal $200 \mu \mathrm{m}$. Legend: cu, cusp; pn, posterior node; wm, white matter.

the beginning of the ontogenetic process of the species. Very juvenile specimens of $E$. rigoi, in fact, already bear a large carinal node behind the cusp (Figure 4.6).
The same growth process may be observed in the other three epigondolellids analyzed: Epigondolella vialovi, E. uniformis, and E. triangularis (Figure 5). The tomographic sections of these species do not have the same quality of those of $E$. 
quadrata and E. rigoi, thus the lamellae of the cusp region are not well distinguishable. Nevertheless, in all the three epigondolellids the posterior node is permeated by a massive occurrence of white matter as in E. rigoi and, in the same way, in the most anterior part of the node the albid tissue appears to be coalescent with that of the cusp (Figure 5). Thus, even if in E. vialovi, E. uniformis, and E. triangularis the growth lines are not well distinguishable, the internal structure of their posterior node is homologous to that of $E$. rigoi and its ontogenesis is seemingly the same. Comparisons with SEM photos of specimens of E. uniformis and E. triangularis from monospecific populations, together with the analyses of their growth series (Mazza and Martínez-Pérez, 2015), confirm the occurrence of the posterior denticle already from the early juvenile stages of these species (Figure 5.3, 5.5).

\section{DISCUSSION}

The evolutionary trends of the Late Triassic $\mathrm{P}_{1}$ conodont elements are quite well defined (see Figure 1; Mazza et al., 2012b). One of the most evident trend is the forward shifting of cusp and pit, which is associated with the occurrence of nodes behind the cusp (Orchard, 2014). This trend also characterizes the evolution of the Late Carnian carnepigondolellids into genera Epigondolella and, later in the Middle Norian, the development of nodes behind the cusp is a character inherited also by the genus Mockina (Mazza et al., 2012a; Mazza and Martínez-Pérez, 2015). The development of the large node behind the cusp in the epigondolellids considerably influenced the phylogenetic model obtained with the cladistic analyses (Mazza et al., 2012b).

The Synchrotron Radiation X-ray Tomographic Microscopy allowed us to investigate in detail the ontogenetic process of this character, revealing that the posterior node of Epigondolella vialovi, E. rigoi, E. uniformis, and E. triangularis is a carinal node because it grows directly from the cusp, while in E. quadrata this node, even if it has the same morphology and is located in the same position of that of the other mentioned epigondolellids, has the same ontogenetic process that leads to the growth of the nodes/denticles developing on the platform margins. For this reason, the posterior node of $E$. quadrata is a different structure than a carinal node, analogous to other platform ornamentation structures (Figures 4, 5). Thus, the large posterior node growing behind the cusp cannot be considered as indicative of common ancestry, as supposed before, but as a clear evolutionary convergence.

Consequently, since different ontogenetic processes for the same morphological character indicate evolutionary convergence, the main question that raises is if the position of Epigondolella quadrata, E. rigoi, E. uniformis, and E. triangularis in the phylogenetic model previously proposed has to be reconsidered. One hypothesis is that the evolution of $E$. quadrata into $E$. rigoi could proceed by the conversion of the posterior node of $E$. quadrata into a carinal node in E. rigoi. Nevertheless, we have to consider that the studies on the Late Triassic conodont growth series (Mazza and MartínezPérez, 2015) revealed that E. quadrata, E. rigoi, and $E$. uniformis first occur quite contemporaneously in the uppermost Carnian and can be found together in a long stratigraphic range until the Middle Norian (Mazza et al., 2012a; Karádi et al., 2013; Mazza and Martinez-Perez, 2015). Juvenile epigondolellids now classifiable as E. triangularis are found in the Tuvalian even below the first occurrences of the other three species (Mazza and Martínez-Pérez, 2015). This suggests that more than being phylogenetically related, these species evolve in parallel lineages, sharing analogous characters. This definitely confirms a new and more articulated scenario for the evolutionary history of the Upper Triassic epigondolellids. Genus Epigondolella cannot be considered anymore as a monophyletic group, but a paraphyletic assemblage of species deriving from Carnian taxa that develop similar morphologies but follow different evolutionary and ontogenetic processes. The previous phylogenetic model has necessarily to be revised.

This aspect raises a considerable transcendence in conodont, as far as their morphology is the base for its systematics and phylogenetic relationships, highlighting the importance of discriminating homology from homoplasy. In this sense, Synchrotron Radiation X-ray Tomographic Microscopy represents a unique and versatile instrument for these kind of investigations, providing data that can inform on conodont ontogenesis, evolutionary processes and phylogenetic relationships.

\section{CONCLUSIONS}

The application of Synchrotron Radiation Xray Tomographic Microscopy to reconstruct the ontogenesis of single Late Triassic conodont $\mathrm{P}_{1}$ elements, suggests that using ontogenesis as a criterion for discriminating homology from homoplasy is actually effective, allowing to identify cryptic 
homology between apparently convergent characters in the conodont platform morphology. In particular, our results about the ontogenesis of the posterior node growing behind the cusp of Late Triassic conodont $\mathrm{P}_{1}$ elements, an autapomorphy characterizing the Epigondolella clade, reveal that the studied character is not a homologous character of the epigondolellids but an evolutionary convergence. Therefore, it cannot be considered as evidence of common ancestry anymore, confirming that the genus Epigondolella is not a monophyletic clade as previously hypothesized, but a polyphyletic assemblage of taxa with different possible ancestors among the carnepigondolellids as later reconsidered. This result highlights the importance to discriminate homology from homoplasy in conodonts to depict more precisely their ontogenetic and evolutionary dynamics.

\section{ACKNOWLEDGEMENTS}

The authors are grateful to P. Donoghue (University of Bristol) for his continuous support and advice, and for giving us access to the TOMCAT beamline (SLS). We thank J. Cunningham, M. Rücklin, J. Keating, and F. Marone for beamline assistance. The authors also thank the two anonymous referees for reviewing the manuscript and the editor C. Haug for her precious suggestions. Research was partially funded by MIUR PRIN (2008BEF5Z7_001; PI M. Balini, Università degli Studi di Milano), by a Marie Curie FP7-People IEF 2011-299681 (CMP), and by the Research Projects CGL2014-52662-P (Spanish Ministry of Economy and Competitiveness) and GV/2016/102 (Generalitat Valenciana).

\section{REFERENCES}

Balini, M., Bertinelli, A., Carter, E.S., Di Stefano, P., Krystyn, L., Levera, M., Mazza, M., McRoberts, C., Muttoni, G., Nicora, A., Orchard, M.J., Preto, N., Rigo, M., Tripodo, A., and Zonneveld J.-P. 2012. Towards the definition of the GSSP of the Norian Stage (Upper Triassic): integrated stratigraphy and correlation of the two candidate sections Black Bear Ridge (BC, Canada) and Pizzo Mondello (Italy). 34th International Geological Congress, Brisbane, Australia, abstract book: 753

Balini, M., Bertinelli, A., Di Stefano, P., Guaiumi, C., Levera, M., Mazza, M., Muttoni, G., Nicora, A., Preto N., and Rigo, M. 2011. The Late Carnian-Rhaetian succession at Pizzo Mondello (Sicani Mountains). Albertiana, 39:36-58.

Balini, M., Di Stefano, P., Tripodo, A., Mazza, M., Levera, M., Muttoni, G., Nicora, A., Rigo, M., and Krystyn, L.
2015. High resolution integrated biomagnetostratigraphy of the Carnian/Norian boundary at Pizzo Mondello and Pizzo Lupo (western Sicily, Italy). Berichte des Institutes für Erdwissenschaften Karl-FranzensUniversität Graz, Band 21:28.

Budurov, K. 1972. Ancyrogondolella triangularis gen. et sp. n. (Conodonta). Mitteilungen der Gesellschaft der Geologie- und Bergbaustudenten in Wien, 21:853860.

Burij, G.I. 1989. Konodonty i stratigrafija Sikhote-Alin. AN SSSR, dalnevostochnoe otdelenie, Vladivostok, Russia. (In Russian)

Donoghue, P.C.J. 1998. Growth and patterning in the conodont skeleton. Philosophical Transactions of the Royal Society, Series B, 353:633-666.

Donoghue, P.C.J. 2001. Conodonts meet cladistics: recovering relationships and assessing the completeness of the conodont fossil record. Palaeontology, 44:65-93.

Donoghue, P.C.J. Purnell, M. A., Aldridge, R. J. and Zhang, S. 2008. The interrelationships of 'complex' conodonts (Vertebrata). Journal of Systematic Palaeontology, 6:119-153.

Dzik, J. 2005. The chronophyletic approach: stratophenetics facing an incomplete fossil record. Special Papers in Palaeontology, 73:159-183.

Epstein, A.G., Epstein, J.B., and Harris, L.D. 1977. Conodont color alteration an index to organic metamorphism. U.S. Geological Survey Professional Papers, 995:27.

Foote, M. and Sepkoski, J.J., Jr. 1999. Absolute measures of the completeness of the fossil record. Nature, 398:415-417.

Jones, D., Evans, A.R., Rayfield, E.J., Siu, K.K.W., and Donoghue, P.C.J. 2012b. Testing micro structural adaptation in the earliest dental tools. Biology Letters, 8:952-955.

Jones, D., Evans, A.R., Siu, K.K.W., Rayfield, E.J., and Donoghue, P.C.J. 2012a. The sharpest tools in the box? Quantitative analysis of conodont element functional morphology. Proceedings of the Royal Society B: Biological Sciences, 279:2849-2854.

Karádi, V., Kozur, H.W,. and Görög, A. 2013. Stratigraphically important Lower Norian Conodonts from the Csovár borehole (CSV-1), Hungary - comparisons with the conodont succession of the Norian GSSP candidate Pizzo Mondello (Sicily, Italy), p. 284-295. In Tanner, L.H., Spielmann, J.A., and Lucas, S.G. (eds.), The Triassic System. New Mexico Museum of Natural History and Science, Bulletin 61. New Mexico Museum of Natural History and Science, Albuquerque.

Marone, F. and Stampanoni, M. 2012. Regridding reconstruction algorithm for real-time tomographic imaging. Journal of Synchrotron Radiation, 19:1029-1037.

Martínez-Pérez, C., Plasencia, P., Jones, D., KolarJurkovšek, T., Sha, J., Botella, H., and Donoghue, P.C.J. 2014b. There is no general model for occlusal kinematics in conodonts. Lethaia, 47:547-555. 
Martínez-Pérez, C., Plasencia, P., Cascales-Miñana, B., Mazza, M., and Botella, H. 2014c. New insights into the diversity dynamics of Triassic conodonts. Historical Biology, 26(5):591-602. doi:10.1080/ 08912963.2013.808632

Martínez-Pérez, C., Rayfield, E.J., Botella, H., and Donoghue, P.C.J. 2016. Translating taxonomy into the evolution of conodont feeding ecology. Geology. 44(4):247-250.

Martínez-Pérez, C., Rayfield, E.J., Purnell, M.A., and Donoghue, P.C.J. 2014a. Finite element, occlusal, microwear and microstructural analyses indicate that conodont microstructure is adapted to dental function. Palaeontology, 57:1059-1066.

Mazza, M., Cau, A., and Rigo, M. 2012b. Application of numerical cladistic analyses to the Carnian-Norian conodonts: a new approach for phylogenetic interpretations. Journal of Systematic Palaeontology, 10(3):401-422.

Mazza, M. and Krystyn, L. 2015. The revised Upper Triassic conodont record of the Tethys: a new step towards a better definition of the conodont bioevents around the base of the Norian stage. Berichte des Institutes für Erdwissenschaften Karl-Franzens-Universität Graz, Band 21:243.

Mazza, M. and Martínez-Pérez, C. 2015. Unravelling conodont (Conodonta) ontogenetic processes in the Late Triassic through growth series reconstructions and X-ray microtomography. Bollettino della Società Paleontologica Italiana, 54 (3):161-186. doi: 10.4435/ BSPI.2015.10

Mazza, M., Rigo, M., and Gullo, M. 2012a. Taxonomy and stratigraphic record of the Upper Triassic conodonts of the Pizzo Mondello section (Western Sicily, Italy), GSSP candidate for the base of the Norian. Rivista Italiana di Paleontologia e Stratigrafia, 118(1):85-130.

Murdock, D.J.E., Rayfield, E.J., and Donoghue, P.C.J. 2014. Functional adaptation underpinned the evolutionary assembly of the earliest vertebrate skeleton. Evolution and Development, 16:354-361.

Muttoni, G., Kent, D.V., Di Stefano, P., Gullo, M., Nicora, A., Tait, J., and Lowrie, W. 2001. Magnetostratigraphy and biostratigraphy of the Carnian/Norian boundary interval from the Pizzo Mondello section (Sicani Mountains, Sicily). Palaeogeography, Palaeoclimatology, Palaeoecology, 166:383-399.

Muttoni, G., Kent, D.V., Olsen, P.E., Di Stefano, P., Lowrie, W., Bernasconi, S.M., and Hernández, F.M. 2004. Tethyan magnetostratigraphy from Pizzo Mondello (Sicily) and correlation to the Late Triassic Newark astrochronological polarity time scale. Geological Society of America Bulletin, 116:1043-1058.

Nicora, A., Balini, M., Bellanca, A., Bertinelli, A., Bowring, S.A., Di Stefano, P., Dumitrica, P., Guaiumi, C., Gullo, M., Hungerbuehler, A., Levera, M., Mazza, M., McRoberts, C.A., Muttoni, G., Preto, N., and Rigo, M. 2007. The Carnian/Norian boundary interval at Pizzo Mondello (Sicani Mountains, Sicily) and its bearing for the definition of the GSSP of the Norian Stage. Albertiana, 36:102-129.

Noyan, O. and Kozur, H. 2007. Revision of the late Carnian-early Norian conodonts from the Stefanion section (Argolis, Greece) and their paleobiogeographic implications. Neues Jahrbuch für Geologie und Paleontologie Abhandlungen, 245(2):159-178.

Orchard, M.J. 1991. Upper Triassic conodont biochronology and new index species from the Canadian Cordillera, p. 299-335. In Orchard, M.J. and McCracken, A.D. (eds.), Ordovician to Triassic conodont paleontology of the Canadian Cordillera. Geological Survey of Canada, Vancouver.

Orchard, M.J. 2014. Conodonts from the Carnian-Norian Boundary (Upper Triassic) of Black Bear Ridge, Northeastern British Columbia, Canada. New Mexico Museum of Natural History and Science Bulletin, 64. New Mexico Museum of Natural History and Science, Albuquerque.

Purnell, M.A. and Jones, D.O. 2012. Quantitative analysis of conodont tooth wear and damage as a test of ecological and functional hypotheses. Paleobiology, 38:605-626.

Rejebian, V.A. 1987. Conodont color and textural alteration: an index to regional metamorphism, contact metamorphism, and hydrothermal alteration. Geological Society of America Bulletin, 99:471-479.

Sweet, W.C. 1988. Oxford Monographs on Geology and Geophysics. The Conodonta: Morphology, Taxonomy, Paleoecology, and Evolutionary History of a Long-Extinct Animal Phylum. Clarendon Press, Oxford.

Wickstrom, L.M. and Donoghue, P.C.J. 2005. Cladograms, phylogenies and the veracity of the conodont fossil record. Special Papers in Palaeontology, 73:185-218.

Zhang, S. and Barnes, C.R. 2004. Conodont bioevents, cladistics and response to glacio-eustasy, Ordovician-Silurian boundary through Llandovery, Anticosti Basin, Que'bec, p. 73-104. In Beaudoin, A.B. and Head, M.J. (eds.), The Palynology and Micropalaeontology of Boundaries, Geological Society of London, Special Publication vol. 230. Geological Society of London, London. 